\title{
Leaf Morphology Variation of Populus nigra L. in Natural Populations along the Rivers in Croatia and Bosnia and Herzegovina
}

\section{Davorin Kajba ${ }^{1 \varangle}$, Dalibor Ballian ${ }^{2}$, Marilena Idžojtić ${ }^{1}$, Igor Poljak ${ }^{1}$}

\author{
${ }^{1}$ University of Zagreb, Faculty of Forestry, Department of Forest Genetic, Dendrology and Botany, Svetoši- \\ munska 25, HR-10000 Zagreb, Croatia \\ ${ }^{2}$ University of Sarajevo, Faculty of Forestry, Department of Silviculture and Urban Greening, Zagrebačka 20, \\ BA-71000 Sarajevo, Bosnia and Herzegovina \\ ${ }^{\otimes}$ Corresponding author: e-mail: davorin.kajba@zg.t-com.hr
}

Citation:

KAJBA D, BALLIAN D, IDŽOJTIĆ M, POLAK I 2015 Leaf Morphology Variation of Populus nigra L. in Natural Populations along the Rivers in Croatia and Bosnia and Herzegovina. South-east Eur for 6 (1): 39-51. DOI: http://dx.doi.org/10.15177/seefor.15-06

\section{Abstract}

Background and Purpose: The aim was to determine the morphological differences between the hairy type of European black poplar (Populus nigra subsp. caudina) and the typical type from the riparian forests populations as well as between the river systems. Hairy black poplar spreads in a mosaic pattern across the Submediterranean climatic type along the River Neretva and the typical European black poplar is growing on alluvial soils along large rivers in the territory of Croatia and Bosnia and Herzegovina.

Material and Methods: Samples for leaf morphometric analysis were collected in 17 natural populations of European black poplar along six rivers in Croatia and Bosnia and Herzegovina.

Results: Discriminant analyses have determined that in the differentiation of population groups largely contribute some characters such as the distance between the leaf widest part and the leaf base (DBW) and the petiole length (PL). The differences between populations and analysed groups, as well as the differences between populations belonging to a particular river system, were confirmed for all studied characteristics.

Conclusions: Significant differences have been determined between the typical and the hairy type of European black poplar in the studied morphological traits and these dissimilarities are in accordance with the climatic differences in respective habitats of continental riparian forests and the Submediterranean type of climate. Populations sampled in the lower course of the River Neretva, which correspond to the hairy type of the European black poplar, have smaller leaves and a greater angle between the first lower lateral vein and the midrib.

Keywords: leaf morphological traits, European black poplar, Populus nigra subsp. caudina, genetic variability 


\section{INTRODUCTION}

The conservation of genetic resources of some forest tree species, particularly the endangered ones, should have high priority in any large-scale programme of forest ecosystem management. The European black poplar (Populus nigra L.) is a species growing on alluvial soils along large rivers in the temperate zones in Europe, Asia and Northern Africa [1]. In the territory of the Republic of Croatia, the European black poplar grows in riparian floodplain forests along rivers Mura, Sava, Drava and the Danube. Its presence in the total forest area of Croatia is small, yet their universal role is significant. Because of continuous human activities in the European black poplar's natural habitats, its range has been reduced to individual, partly separated areas only, although for the European conditions the habitats are very well preserved riparian forests [2]. The overall length of rivers and creeks in Bosnia and Herzegovina is around $11000 \mathrm{~km}$, but the habitats of European black poplar are limited only to the valleys of bigger rivers, such as Drina, Bosna, Una, Sana and Neretva with the total length of $1200 \mathrm{~km}$ [3]. In Herzegovina, along the River Neretva, a special subspecies of black poplar can be found, known as the hairy poplar (P. nigra subsp. caudina), which is characterised by distinctly hairy shoots and leaves [4]. Hairiness retains on one-year and two-year-old shoots and partially on older shoots as well. Apart from the leaves and shoots, the petioles of inflorescence and fruits are also permanently hairy. So far, these poplars have been recorded in two more southern Balkan areas, in southern Macedonia and in Thessaly in central Greece, while some populations from Albania and Turkey have also attributed to this taxon [5-7]. The studied population of the hairy type of black poplar is found in the Submediterranean type of climate. This climate is characterised by mild winters and dry summers. The value of gene conservation in these populations may be crucial for the whole species with regard to the trends of climate changes [8-11]. The survival of the European black poplar, as an autochthonous species, has been endangered also by the cultivation of superior hybrids of Euroamerican poplars $(P . \times$ canadensis) and Eastern Cottonwood (P. deItoides) clones within the area of its natural range. Some of these imported clones were female and their flowering was synchronized with the European black poplar. Crossing between these various poplar species is possible and the question is whether in the European black poplar juvenile populations there is the introgression of the Eastern Cottonwood genes or the Euroamerican hybrid genes [12-14]. The genetic resources of the European black poplar are also threaten by a non-planned land use along the rivers, the regulation of river flows, gravel pits, dumps, and the lack of legislative regulations.

In this study the intention is, apart from hairiness, to find out which dissimilarities can be found in other morphological traits of the leaves of the typical and hairy black poplar, as well as between the populations and the rivers' systems. It also examines the importance of the hairy type of the European black poplar concerning conservation and the breeding of poplars with regard to the increasing effect of climate changes [15].

\section{MATERIALS AND METHODS}

The samples for leaf morphometric analysis were collected in 17 natural populations of the European black poplar in the area of Croatia and Bosnia and Herzegovina (Figure 1). In Croatia, the investigations were conducted among five populations along the basin of the River Drava (Žirovnjak, Tršćana, Bobrovac, Šućurica and Topolje) and three populations along the River Sava (Jarun, Zaprešić 1, Zaprešić 2) from 5 to 15 years old. In Bosnia and Herzegovina the samples were collected in nine populations from four rivers: one population was along the River Drina (Tegare), two populations were collected along the River Vrbas and the River Bosna (Zlavast, Banja Luka, Bilješevo, Doboj) and four populations were sampled along the River Neretva (Ovčari, Počitelj, Čapljina, Metković), all being at the age up to mature trees (30 years). 


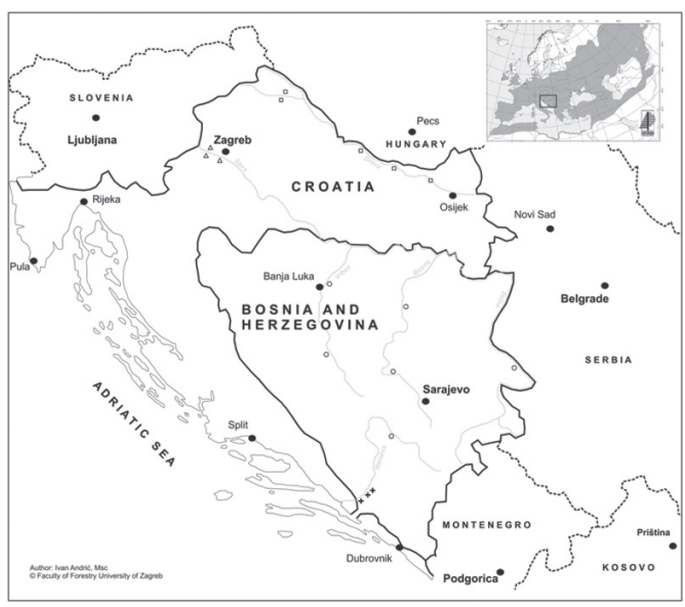

FIGURE 1. The location of the analyzed Populus nigra populations (after Vanden Broeck 2003)

To simplify the processing of data, the studied populations were divided into four separate groups according to the ecogeographical zones. Groups CRO-01 and CRO-02 belong to Croatian rivers (Drava and Sava). Group B\&H-01 is com- posed of six populations from the inner part of Bosnia and Herzegovina and group B\&H-02 consists of three populations that were sampled in the lower course of the River Neretva in the Submediterranean region. Leaf samples were collected from short fertile shoots and in total the analysis included 514 trees and 6513 leaves, from which 32565 data have been measured and statistically processed (Table 1).

The fully developed, undamaged European black poplar leaves have been investigated [16]. Within one tree the leaf dimorphism and the seasonal heterophylly in poplars was also found $[17,18]$. The leaves were taken only from short shoots only in the central part of tree crown, which proved to give a more reliable description of the studied morphological properties than the leaves from the long shoots [19-21].

The measurements of the following morphological parameters have been taken: leaf blade length (LBL), leaf blade width (LBW), petiole length ( $\mathrm{PL})$, the angle between the first lower lateral vein and the midrib $(\alpha)$ and the distance

TABLE 1. Sampled populations

\begin{tabular}{lllllllc}
\hline Group & Population & Locality & N & $\mathbf{n}$ & Latitude & Longitude & $\begin{array}{c}\text { Altitude } \\
(\mathrm{m})\end{array}$ \\
\hline CRO-01 & Drava 1 & Žirovnjak & 60 & 300 & $46^{\circ} 19^{\prime} \mathrm{N}$ & $16^{\circ} 43^{\prime} \mathrm{E}$ & 139 \\
& Drava 2 & Tršćana & 60 & 300 & $46^{\circ} 15^{\prime} \mathrm{N}$ & $16^{\circ} 44^{\prime} \mathrm{E}$ & 149 \\
& Drava 3 & Bobrovac & 60 & 300 & $45^{\circ} 48^{\prime} \mathrm{N}$ & $17^{\circ} 47^{\prime} \mathrm{E}$ & 102 \\
& Drava 4 & Šućurica & 60 & 300 & $45^{\circ} 46^{\prime} \mathrm{N}$ & $18^{\circ} 11^{\prime} \mathrm{E}$ & 88 \\
& Drava 5 & Topolje & 60 & 300 & $45^{\circ} 40^{\prime} \mathrm{N}$ & $18^{\circ} 30^{\prime} \mathrm{E}$ & 99 \\
\hline CRO-02 & Sava 1 & Jarun & 52 & 260 & $45^{\circ} 46^{\prime} \mathrm{N}$ & $15^{\circ} 55^{\prime} \mathrm{E}$ & 117 \\
& Sava 2 & Zaprešić 1 & 33 & 165 & $45^{\circ} 50^{\prime} \mathrm{N}$ & $15^{\circ} 46^{\prime} \mathrm{E}$ & 131 \\
& Sava 3 & Zaprešić 2 & 40 & 200 & $45^{\circ} 49^{\prime} \mathrm{N}$ & $15^{\circ} 48^{\prime} \mathrm{E}$ & 125 \\
\hline B\&H-01 & Bosna 1 & Bilješevo & 10 & 500 & $44^{\circ} 07^{\prime} \mathrm{N}$ & $18^{\circ} 00^{\prime} \mathrm{E}$ & 357 \\
& Bosna 2 & Doboj & 10 & 500 & $44^{\circ} 45^{\prime} \mathrm{N}$ & $18^{\circ} 06^{\prime} \mathrm{E}$ & 141 \\
& Vrbas 1 & Zlavast & 10 & 500 & $44^{\circ} 01^{\prime} \mathrm{N}$ & $17^{\circ} 29^{\prime} \mathrm{E}$ & 580 \\
& Vrbas 2 & Banja Luka & 10 & 500 & $44^{\circ} 46^{\prime} \mathrm{N}$ & $17^{\circ} 13^{\prime} \mathrm{E}$ & 154 \\
& Drina 1 & Tegare & 11 & 550 & $44^{\circ} 08^{\prime} \mathrm{N}$ & $19^{\circ} 26^{\prime} \mathrm{E}$ & 180 \\
& Neretva 1 & Ovčari & 10 & 488 & $43^{\circ} 41^{\prime} \mathrm{N}$ & $17^{\circ} 59^{\prime} \mathrm{E}$ & 330 \\
\hline B\&H-02 & Neretva 2 & Počitelj & 7 & 300 & $43^{\circ} 08^{\prime} \mathrm{N}$ & $17^{\circ} 43^{\prime} \mathrm{E}$ & 15 \\
& Neretva 3 & Čapljina & 13 & 650 & $43^{\circ} 07^{\prime} \mathrm{N}$ & $17^{\circ} 42^{\prime} \mathrm{E}$ & 10 \\
& Neretva 4 & Metković & 8 & 400 & $43^{\circ} 03^{\prime} \mathrm{N}$ & $17^{\circ} 41^{\prime} \mathrm{E}$ & 3 \\
\hline
\end{tabular}

$\mathrm{N}$ - number of sampled trees; $\mathrm{n}$ - number of sampled leaves 
between the leaf widest part and the leaf base (DBW), as shown in Figure 2.

Measured morphological traits were summarized using descriptive statistical parameters, with standard algorithms using descriptive statistical analysis [22]. Data are presented following univariate statistical parameters: arithmetical mean (M), standard deviation (SD) and the coefficient of variation (CV). Statistically significant differences between the investigated objects were determined using univariate nonparametric Kruskal-Wallis analysis of variance tests (Kruskal-Wallis ANOVA).

The analysis was carried out on the entire sample in a manner that examined differences between all populations, among the groups CRO-01, CRO-02, B\&H-01 and B\&H-02, between the groups CRO-01 and CRO-02, groups $\mathrm{B} \& \mathrm{H}-01$ and $\mathrm{B} \& \mathrm{H}-02$ and between the populations on the basis of belonging to a particular river system.

According to McGarigal et al. [23], multivariate statistical methods were used (the

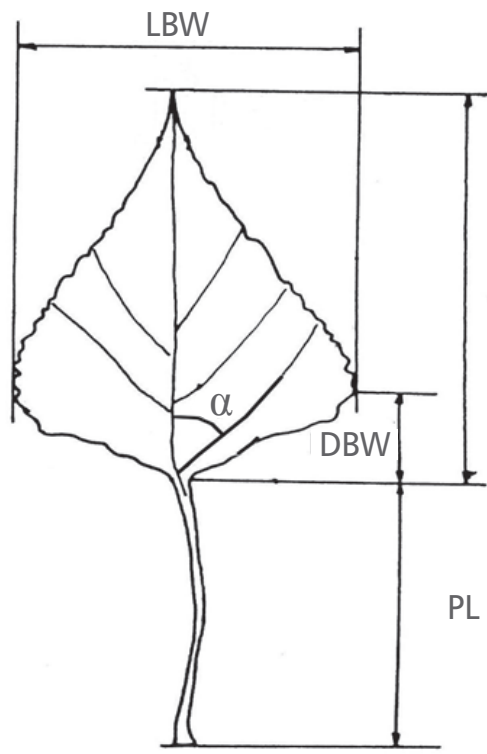

FIGURE 2. The investigated leaf morphological traits (LBL - leaf blade length, LBW - leaf blade width, DBW - distance between the leaf widest part and the leaf base, PL - petiole length, $\alpha$ angle between the first lower lateral vein and the midrib). principal components analysis and the discriminant analysis) to show the similarities or the differences between the studied populations and groups on the basis of the measured morphological characteristics of leaves. In both analyses the arithmetic means of each population for each parameter were used. Five principal components in total were derived by principal component analysis. The first two of them were selected by Kaiser criterion (eigenvalue greater than 1) for further analysis of relations between populations [24]. When it comes to the interpretation of the results, the first two principal components are shown in the graph to determine the trend of the relationship between the populations. To determine the features that best distinguish predefined groups, a discriminant analysis was carried out. These statistical analyses were performed using the statistical program STATISTICA 8.0 [25].

\section{RESULTS}

The results of the descriptive statistical analysis in Table 2 are shown according to the populations, and in Table 3 are listed according to the investigated groups. The results show that the Croatian population from the group CRO-01 has the highest average values for the traits such as leaf blade length (LBL), leaf blade width (LBW), the distance between the leaf widest part and the leaf base (DBW) and the petiole length $(\mathrm{PL})$. On the contrary, the highest average values for the trait angle between the first lower lateral vein and the midrib $(\alpha)$ were peculiar to populations from the group CRO-2. The two groups of studied populations from Bosnia and Herzegovina had larger and wider leaf blades ( $\mathrm{LBL}, \mathrm{LBW}$ ) and longer petioles (PL) that characterized populations from the inner part of Bosnia and Herzegovina (group B\&H-01). Populations which were sampled in the lower course of the River Neretva (group of B\&H02), except that they had smaller leaves, also had the higher values for the angle between the first lower lateral vein and the midrib $(\alpha)$. Also it can be seen that the highest degree of 
TABLE 2. Descriptive statistics of the measured morphological traits at the population level

\begin{tabular}{|c|c|c|c|c|c|c|c|c|c|c|}
\hline \multirow{2}{*}{ Population } & \multicolumn{2}{|c|}{ LBL $(\mathrm{cm})$} & \multicolumn{2}{|c|}{ LBW $(\mathrm{cm})$} & \multicolumn{2}{|c|}{ DBW $(\mathrm{cm})$} & \multicolumn{2}{|c|}{$\mathrm{PL}(\mathrm{cm})$} & \multicolumn{2}{|l|}{$\alpha\left({ }^{\circ}\right)$} \\
\hline & $M \pm S D$ & CV & $M \pm S D$ & CV & $M \pm S D$ & CV & $M \pm S D$ & CV & $M \pm S D$ & CV \\
\hline Drava 1 & $5.5 \pm 1.18$ & 21.5 & $4.5 \pm 0.97$ & 21.3 & $2.0 \pm 0.43$ & 21.5 & $3.2 \pm 0.99$ & 30.9 & $38.9 \pm 5.56$ & 14.3 \\
\hline Drava 2 & $5.5 \pm 1.06$ & 19.4 & $4.2 \pm 0.87$ & 20.8 & $2.0 \pm 0.43$ & 21.2 & $3.0 \pm 0.86$ & 29.1 & $36.9 \pm 5.21$ & 14.1 \\
\hline Drava 3 & $4.5 \pm 1.14$ & 25.4 & $3.9 \pm 0.91$ & 23.7 & $1.7 \pm 0.42$ & 24.9 & $2.9 \pm 0.94$ & 33.1 & $39.7 \pm 6.37$ & 16.0 \\
\hline Drava 4 & $5.1 \pm 1.06$ & 20.6 & $4.4 \pm 0.95$ & 21.7 & $1.9 \pm 0.45$ & 23.2 & $3.0 \pm 0.93$ & 31.2 & $39.8 \pm 6.56$ & 16.5 \\
\hline Drava 5 & $4.6 \pm 0.99$ & 21.5 & $4.0 \pm 0.83$ & 21.0 & $1.8 \pm 0.39$ & 22.0 & $2.9 \pm 0.95$ & 32.8 & $40.0 \pm 6.06$ & 15.1 \\
\hline Sava 1 & $4.4 \pm 1.09$ & 24.8 & $3.3 \pm 0.94$ & 28.1 & $1.7 \pm 0.46$ & 27.2 & $2.2 \pm 0.81$ & 37.3 & $34.4 \pm 7.77$ & 22.6 \\
\hline Sava 2 & $4.9 \pm 1.10$ & 22.2 & $3.8 \pm 0.95$ & 25.1 & $1.9 \pm 0.53$ & 27.2 & $2.4 \pm 0.79$ & 33.0 & $33.2 \pm 8.25$ & 24.8 \\
\hline Sava 3 & $4.9 \pm 1.11$ & 22.7 & $3.6 \pm 0.85$ & 23.3 & $1.8 \pm 0.52$ & 28.3 & $2.5 \pm 0.85$ & 33.8 & $32.8 \pm 8.36$ & 25.5 \\
\hline Bosna 1 & $6.3 \pm 0.86$ & 13.6 & $4.8 \pm 0.57$ & 12.0 & $1.7 \pm 0.28$ & 16.0 & $3.8 \pm 0.74$ & 19.4 & $42.7 \pm 7.72$ & 18.1 \\
\hline Bosna 2 & $6.4 \pm 1.15$ & 17.9 & $4.9 \pm 0.81$ & 16.3 & $1.8 \pm 0.39$ & 21.2 & $3.7 \pm 0.86$ & 22.9 & $42.3 \pm 6.44$ & 15.2 \\
\hline Vrbas 1 & $6.1 \pm 0.70$ & 11.4 & $4.8 \pm 0.50$ & 10.4 & $1.9 \pm 0.30$ & 15.7 & $3.9 \pm 0.62$ & 16.0 & $39.7 \pm 5.44$ & 13.7 \\
\hline Vrbas 2 & $6.3 \pm 077$ & 12.2 & $4.7 \pm 0.57$ & 12.1 & $1.7 \pm 0.27$ & 15.8 & $3.7 \pm 0.77$ & 20.8 & $42.0 \pm 8.15$ & 19.4 \\
\hline Drina & $6.7 \pm 0.92$ & 13.6 & $4.8 \pm 0.66$ & 13.7 & $1.9 \pm 0.35$ & 18.8 & $3.8 \pm 0.88$ & 23.3 & $41.3 \pm 6.14$ & 14.9 \\
\hline Neretva 1 & $6.0 \pm 0.72$ & 12.0 & $4.6 \pm 0.53$ & 11.6 & $1.7 \pm 0.25$ & 15.1 & $3.3 \pm 0.65$ & 19.5 & $41.0 \pm 8.43$ & 20.6 \\
\hline Neretva 2 & $5.1 \pm 0.71$ & 13.9 & $3.7 \pm 0.54$ & 14.7 & $1.7 \pm 0.41$ & 24.3 & $2.3 \pm 0.69$ & 30.1 & $45.7 \pm 6.75$ & 14.8 \\
\hline Neretva 3 & $5.0 \pm 0.67$ & 13.5 & $3.6 \pm 0.48$ & 13.5 & $1.6 \pm 0.25$ & 16.1 & $2.0 \pm 0.46$ & 23.0 & $43.3 \pm 6.43$ & 14.8 \\
\hline Neretva 4 & $5.1 \pm 0.94$ & 18.5 & $3.8 \pm 0.64$ & 16.8 & $1.7 \pm 0.38$ & 22.4 & $2.3 \pm 0.54$ & 23.2 & $45.7 \pm 6.26$ & 13.7 \\
\hline
\end{tabular}

LBL - leaf blade length; LBW - leaf blade width; DBW - distance between the leaf widest part and the leaf base; $\mathrm{PL}$ - petiole length; $\alpha$ - angle between the first lower lateral vein and the midrib;

$\mathrm{M}$ - average value; SD - standard deviation; CV - coefficient of variation (\%)

variability shows the trait of petiole length $(\mathrm{PL})$ as it is shown in Tables 2 and 3. Higher variability for all measured characters for Croatian river populations was determined for the group CRO02 (the River Sava) and in Bosnia and Herzegovina for the group B\&H-02 (lower part of the River
Neretva), except for the trait angle between the first lower lateral vein and the midrib $(\alpha)$, which shows a slightly greater degree of variability.

The differences between populations and analysed groups, as well as the differences between the populations belonging to a particular

TABLE 3. Descriptive statistics of the measured morphological traits at the group level

\begin{tabular}{lcccccccccc}
\hline \multirow{2}{*}{ Population } & \multicolumn{2}{c}{ LBL $(\mathrm{cm})$} & \multicolumn{2}{c}{ LBW $(\mathrm{cm})$} & \multicolumn{2}{c}{ DBW $(\mathrm{cm})$} & \multicolumn{2}{c}{ PL $(\mathrm{cm})$} & \multicolumn{2}{c}{$\alpha\left(^{\circ}\right)$} \\
\cline { 2 - 11 } & M \pm SD & CV & M \pm SD & CV & M \pm SD & CV & M \pm SD & CV & M \pm SD & CV \\
\hline CRO-01 & $5.0 \pm 1.16$ & 23.1 & $4.2 \pm 0.94$ & 22.5 & $1.9 \pm 0.44$ & 23.4 & $3.0 \pm 0.94$ & 31.6 & $39.1 \pm 6.07$ & 15.6 \\
CRO-02 & $4.7 \pm 1.13$ & 24.1 & $3.5 \pm 0.93$ & 26.2 & $1.8 \pm 0.51$ & 28.1 & $2.3 \pm 0.83$ & 35.5 & $33.6 \pm 8.11$ & 24.2 \\
B\&H-01 & $6.3 \pm 0.90$ & 14.2 & $4.8 \pm 0.62$ & 13.1 & $1.8 \pm 0.32$ & 18.0 & $3.7 \pm 0.78$ & 21.0 & $41.5 \pm 7.19$ & 17.3 \\
B\&H-02 & $5.0 \pm 0.77$ & 15.3 & $3.7 \pm 0.55$ & 15.1 & $1.6 \pm 0.34$ & 20.8 & $2.2 \pm 0.57$ & 26.4 & $44.6 \pm 6.56$ & 14.7 \\
B\&H-02 & $5.0 \pm 0.77$ & 15.3 & $3.7 \pm 0.55$ & 15.1 & $1.6 \pm 0.34$ & 20.8 & $2.2 \pm 0.57$ & 26.4 & $44.6 \pm 6.56$ & 14.7 \\
\hline
\end{tabular}

LBL - leaf blade length; LBW - leaf blade width; DBW - distance between the leaf widest part and the leaf base; $P L$ - petiole length; $\alpha$ - angle between the first lower lateral vein and the midrib;

$\mathrm{M}$ - average value; SD - standard deviation; CV - coefficient of variation (\%) 
river system, were confirmed for all studied characteristics. Table 4 shows the results of non-parametric univariate analysis of variance (Kruskal-Wallis ANOVA). Analysed populations and groups, as well as the populations belonging to a particular river system, differ from each other with statistical significance level of 0.0001 for all the measured characters of leaves.

The results of the principal component analysis show that the cumulative variability captured for the first two PC-axes is approximately $90 \%$, with the largest share of the first PC-axis of approximately $60 \%$ (Table 5). The remaining three axes, whose eigenvalue is less than 1 in total variability, contribute to only about $10 \%$ and can be ignored. The contribution of each of the measured morphological characters to the each of the calculated PC-axis is shown in Table 6 . Figure 3 shows the relation between studied populations based on the first and second principal components. From the Table 6 we can assume that all of the original variables are positively correlated with the first principal component, regarding that from the right side of the diagram populations with larger leaves are grouped and on the left side populations with smaller leaves. The distribution of the studied populations along the second PC-axis largely

TABLE 4. Kruskal-Wallis ANOVA for the measured morphological traits

Analyse 1 - population: $\mathrm{H}(16, \mathrm{~N}=6513) ; \mathrm{p}=0,0001 ; \chi^{2}=$ Chi-Square test $(\mathrm{df}=16)$.

Analyse 2 - river: $\mathrm{H}(5, \mathrm{~N}=6513) ; \mathrm{p}=0,0001 ; \chi^{2}=$ Chi-Square test $(\mathrm{df}=5)$.

Analyse 3 - group: $\mathrm{N}=6513) ; \mathrm{p}=0,0001 ; \chi^{2}=$ Chi-Square test $(\mathrm{df}=3)$.

Analyse $4-$ CRO-01/CRO-02: $\mathrm{H}(1, \mathrm{~N}=2125) ; \mathrm{p}=0,0001 ; \chi^{2}=$ Chi-Square test $(\mathrm{df}=1)$.

Analyse $5-\mathrm{B} \& \mathrm{H}-01 / \mathrm{B} \& \mathrm{H}-02: \mathrm{H}(1, \mathrm{~N}=4388) ; \mathrm{p}=0,0001 ; \chi^{2}=$ Chi-Square test $(\mathrm{df}=1)$.

\begin{tabular}{|c|c|c|c|c|c|c|}
\hline \multirow{2}{*}{ Analyse } & \multirow{2}{*}{$\begin{array}{c}\text { Kruskal-Wallis } \\
\text { test }\end{array}$} & \multicolumn{5}{|c|}{ Morphological trait } \\
\hline & & LBL & LBW & DBW & PL & $\alpha\left(^{\circ}\right)$ \\
\hline \multirow[t]{2}{*}{ Population } & $\mathrm{H}$ & 2592.36 & 2433.03 & 691.07 & 2992.43 & 1114.49 \\
\hline & $\chi^{2}$ & 2027.61 & 2131.20 & 504.51 & 2451.45 & 713.73 \\
\hline \multirow[t]{2}{*}{ River } & $\mathrm{H}$ & 2052.17 & 1815.07 & 384.41 & 2346.392 & 932.15 \\
\hline & $\chi^{2}$ & 1555.63 & 1549.97 & 284.91 & 1910.51 & 575.99 \\
\hline \multirow[t]{2}{*}{ Group } & $\mathrm{H}$ & 2304.53 & 2263.87 & 328.65 & 2835.83 & 977.52 \\
\hline & $\chi^{2}$ & 1871.01 & 2044.90 & 233.19 & 2323.13 & 584.83 \\
\hline CRO-01/ & $\mathrm{H}$ & 41.68 & 197.18 & 17.73 & 204.18 & 293.32 \\
\hline CRO-02 & $\chi^{2}$ & 36.62 & 133.44 & 6.97 & 149.31 & 273.09 \\
\hline B\&H-01/ & $\mathrm{H}$ & 1518.47 & 1899.93 & 223.40 & 2275.50 & 148.79 \\
\hline B\&H-02 & $\chi^{2}$ & 1044.38 & 1418.36 & 158.40 & 1589.24 & 88.97 \\
\hline
\end{tabular}

LBL - leaf blade length; LBW - leaf blade width; DBW - distance between the leaf widest part and the leaf base; $\mathrm{PL}$ - petiole length; $\alpha$ - angle between the first lower lateral vein and the midrib

TABLE 5. Eigenvalues, the percent of variance and cumulative variance

\begin{tabular}{ccccc}
\hline $\begin{array}{c}\text { Main } \\
\text { components }\end{array}$ & Eigenvalue & \% Total Variance & $\begin{array}{c}\text { Cumulative } \\
\text { Eigenvalue }\end{array}$ & Cumulative \% \\
\hline 1 & 2.992682 & 59.85364 & 2.992682 & 59.8536 \\
2 & 1.498491 & 29.96981 & 4.491173 & 89.8235 \\
3 & 0.352645 & 7.05290 & 4.843818 & 96.8764 \\
4 & 0.136580 & 2.73159 & 4.980397 & 99.6079 \\
5 & 0.019603 & 0.39205 & 5.000000 & 100.0000 \\
\hline
\end{tabular}




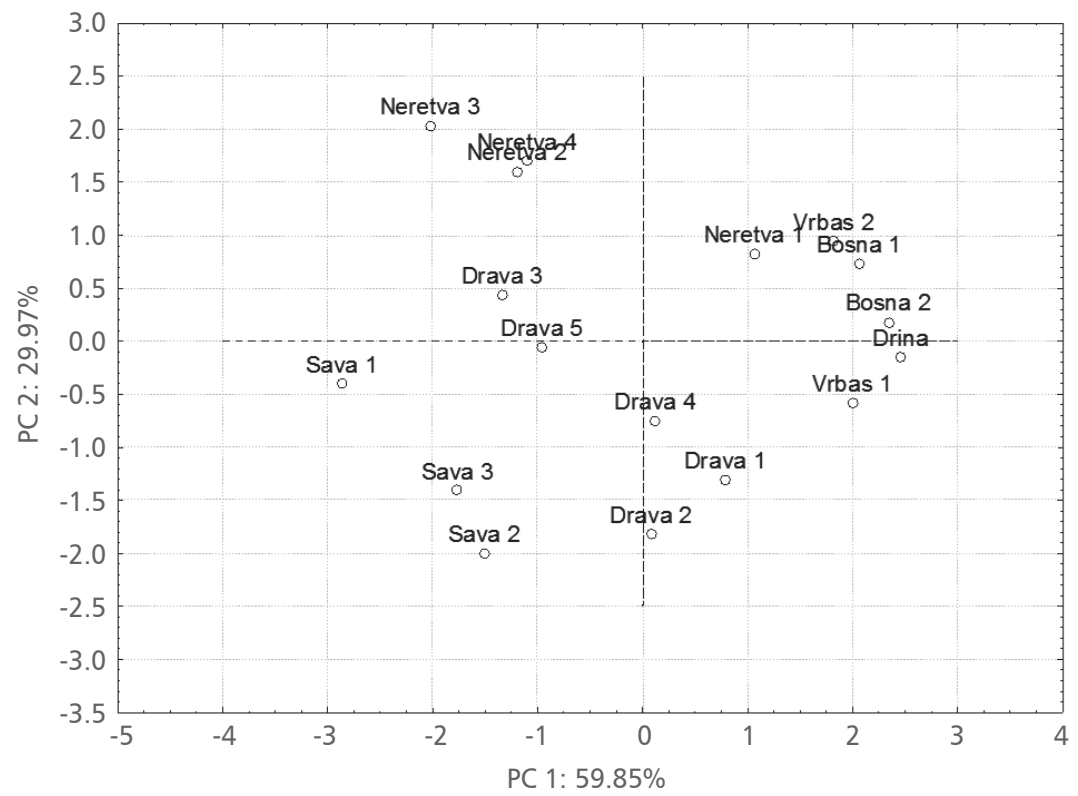

FIGURE 3. Scatterplot of the PC analysis for 17 studied populations of Populus nigra. Particular values for the first PC are on the $x$ axis, and for the second PC on the $y$ axis.

contributes to a positive correlation for the trait angle between the first lower lateral vein and the midrib $(\alpha)$, and a negative correlation for the character distance between the leaf widest part and the leaf base (DBW).

The discriminant analysis was used to determine which leaf morphological characters best separate the studied groups. The results of the discriminant analysis suggest that the variability between the experimental groups is significant (Wilk's $\lambda=0.00032$; $F(15,25)=29.336 ; p<0.00001)$. For five varia- bles and four groups of canonical analysis, three discriminant functions were obtained. From the means of the canonical variables it is evident that the discriminant function 1 in the fullest extent particularly distinguishes group B\&H-01 from other studied groups (Figure 4, Table 7). In the Table 8 it is evident that in this differentiation largely contribute characters such as the distance between the leaf widest part and the leaf base (DBW) and petiole length (PL). Since this table contains the eigenvalue and the cumulative proportion of the explained

TABLE 6. Factor-variable correlations (factor loadings)

\begin{tabular}{lccccc}
\hline \multicolumn{1}{c}{ Variable } & Factor $\mathbf{1}$ & Factor $\mathbf{2}$ & Factor $\mathbf{3}$ & Factor $\mathbf{4}$ & Factor 5 \\
\hline LBL & 0.546315 & 0.080723 & -0.151271 & 0.804953 & 0.155539 \\
LBW & 0.571610 & -0.040310 & -0.016851 & -0.235424 & -0.784812 \\
PL & 0.554369 & -0.074487 & -0.276459 & -0.531439 & 0.572949 \\
DBW & 0.165978 & -0.711838 & 0.668192 & 0.060142 & 0.125061 \\
$\alpha\left({ }^{\circ}\right)$ & 0.199824 & 0.692529 & 0.673739 & -0.102872 & 0.126362 \\
\hline
\end{tabular}

LBL - leaf blade length; LBW - leaf blade width; DBW - distance between the leaf widest part and the leaf base; $\mathrm{PL}$ - petiole length; $\alpha$ - angle between the first lower lateral vein and the midrib 


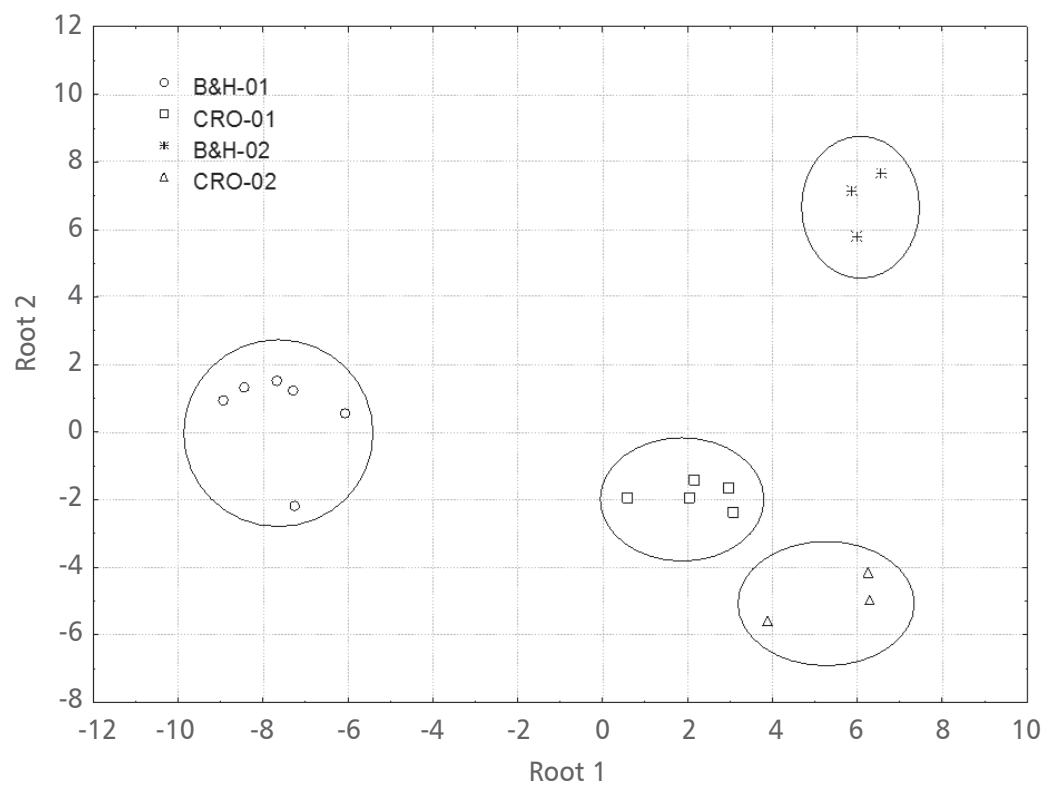

FIGURE 4. Scatterplot of the canonical scores for four studied groups of Populus nigra. Particular values for the first discriminant function are on the $x$ axis, and for the second function on the $y$ axis

variation for each discriminant function, it can be determined that the discriminant function 1 contains $68.2 \%$ of the explained variability. The discriminant function 2, which together with discriminant function 1 explains $95.9 \%$ of the variability, clearly distinguished group of $\mathrm{B} \& \mathrm{H}-02$ from the other three studied populations which were sampled on the River Sava and which belong to the group CRO-02 (Figure 4, Table 7). Variables $\alpha$ (the angle between the first lower lateral vein and the midrib) and LBL (leaf blade length) largely contribute in the differentiation between these two groups, as it is shown in Table 8. The third discriminant function, which explains only $4.1 \%$ of the total variability, best

TABLE 7. Means of canonical variables

\begin{tabular}{cccc}
\hline Group & Root 1 & Root 2 & Root 3 \\
\hline B\&H-01 & -7.60668 & 0.57274 & -0.43766 \\
CRO-01 & 2.15751 & -1.86648 & 2.01742 \\
B\&H-02 & 6.14944 & 6.86594 & -0.45985 \\
CRO-02 & 5.46808 & -4.90061 & -2.02719 \\
\hline
\end{tabular}

distinguished the two groups of Croatian population belonging to the basin of the River Drava and the River Sava (Table 7).

\section{DISCUSSION}

Interpopulation variability and the variation between the river systems were statistically significant for all the investigated morphological traits that correspond to the previous research in the juvenile populations of the European black poplaralong the River Drava and the River Sava[19, $20,26]$. Some of the morphological parameters, such as petiole length (PL), show a statistically important difference between the investigated populations, and have also been determined in previous investigations [26]. Interpopulation variability in the Danube basin was in most of morphological characters between 10 and $20 \%$ [27]. The highest contribution of variation between populations had a number of veins on the left and the right blade side. The highest contribution of variation within the populations 
TABLE 8. Standardised coefficients for canonical variables

\begin{tabular}{lccc}
\hline \multicolumn{1}{c}{ Variable } & Root 1 & Root 2 & Root 3 \\
\hline LBL & -0.67926 & 1.00828 & -1.42333 \\
LBW & -0.55689 & -0.59956 & 0.81317 \\
PL & -1.05147 & -0.43264 & 0.13713 \\
DBW & 1.82785 & 0.19787 & 0.82135 \\
$\alpha\left(^{\circ}\right)$ & 0.36774 & 1.13227 & 0.40122 \\
\hline Eigenvalue & 44.12233 & 17.91218 & 2.65094 \\
\hline Cumulative proportion & 0.68211 & 0.95902 & 1.00000 \\
\hline of explained variation & &
\end{tabular}

LBL - leaf blade length; LBW - leaf blade width; DBW - distance between the leaf widest part and the leaf base; $\mathrm{PL}$ - petiole length; $\alpha$ - angle between the first lower lateral vein and the midrib

(more than 50\%) had a distance between the base of the leaf blade and the widest part [27]. This character corresponds to the results of the interpopulation differentiation in our study. The mentioned characters is under a genetic control and is less influenced by the environmental changes, so it could serve to estimate the intrapopulation and interpopulation variability, as well as to show the introgression of the genes of other poplar species in local population of the European black poplar. The morphological variation of seven leaf characters from 84 trees of eastern cottonwood (Populus deltoides Bartr. ex. Marsh. var. deltoides) from nine populations in Ontario was also studied [28]. Leaf characters showed significant variation among populations $(P \leq 0.003)$ and the number of veins showed a significant correlation with the longitude $(r=0.81, P<0.009)$ and the latitude $(r=-0.69$, $P<0.05)$. None of the other leaf characters were related to latitude and longitude.

The genetic diversity of ten black poplar populations along the main river systems across Slovenia and Croatia (rivers Soča, Sava, Drava and Mura) was revealed by using six microsatellite loci [29]. The results of this study indicate that the gene pool of the remaining Populus nigra populations in this territory is still well preserved. In natural populations, the introgression of the genes of Populus deltoides was very low. One of the populations along the River Drava
(Suhopolje, near locality Šućurica, population Drava 4 in Table 1 and 2) was distinct from the others and clustered alone as a separate group.

The assessment of the population genetic structure of the Populus nigra L. along the rivers revealed a significant spatial genetic structure which was probably caused by a limited gene flow. This helps to explain the reduced diversity in the juveniles [30-32].

The results of the research of the European black poplar leaf morphological variability in the natural stands along the Sava and Drava show that in the studied progeny the phenotypes resemble each other and mostly prevail among the European black poplar [19, 20, 29] with no introgression with $P$. deltoides or poplar hybrids. These results confirm the researches of Van den Broeck et al. [1, 34] carried out in Belgium. By studying the poplar flowering phenology in clonal archives they noted that the male poplar clone ( $P$. nigra var. italica) and 22 clones of $P . \times$ canadensis flower earlier than the studied clones of local European black poplar (P. nigra). Based on this finding, they concluded that there is no great danger of the introgression of the American black poplar genes into the European black poplar genom, but also that the introgression of genes should not be excluded completely, having in mind that considerable variations in the poplar flowering phenology have been noticed. 
Leaf morphometric characters have significantly contributed in the intra- and interpopulation variability of Populus nigra populations in the basin of the River Danube [27]. The discriminative model with all characters achieved less than $60.38 \%$ of correct allocation due to a high variability of examined characters within populations. The results of morphological analysis do not entirely support the results of the molecular analysis, but they generally support the similarity among neighbouring populations and, according to this, the results provide a proper selection and the use of forest reproductive material.

Hairy subspecies of European black poplar (Populus nigra subsp. caudina) spreads in a mosaic pattern across a warm and dry area of Herzegovina along the River Neretva, while along the rivers in the region of central and mountainous Bosnian belt only individual trees are mixed with the typical black poplar. It can be assumed that the area of its current distribution range is what has been left of its former and probably much larger population [6]. The habitat of the hairy European black poplar in Herzegovina is the consequence of ecogeographical conditions and of rather historical factors and their effect on the development of flora in that area. This belief leads to the idea that the current distribution of the hairy black poplar is a result of a recent spread of the black poplar from the North (from the River Drava and the River Sava, Groups CRO-01 and CRO-02) toward the South. Individual trees of the hairy black poplar in northern and central Bosnia grow at higher altitudes, in the colder and more humid mountainous region [4]. The isolated Submediterranean populations (Group B\&H-02), growing along the River Neretva, can be found at $15 \mathrm{~m}$ a.s.l. The average temperature during vegetation period ranges between $15.9^{\circ} \mathrm{C}$ and $16.9^{\circ} \mathrm{C}$ for populations from inner Bosnia and Herzegovina (Group B\&H-01) and is $20.7^{\circ} \mathrm{C}$ for populations from the lower course of the River Neretva (Group B\&H-02). Ecological and climate conditions along the River Neretva are completely different with characteristically long, warm and dry summers (with the average precipitation of $365 \mathrm{~mm}$ in vegetation period). Moreover, these conditions are characterised by a distinctive fluctuation in the water level, as well as the saturation of the pedological layer with lime-stones. We can assume that the hairy black poplar found along the River Neretva is a remnant of an earlier continuous land area, spreading from Greece to Herzegovina via Macedonia and Albania. The hairy type of black poplar ( $P$. nigra subsp. caudina) growing along the River Neretva differs considerably from the black poplar in the riparian populations along the European rivers. This rare hairy type of $P$. nigra is considered to be a xeromorphic form in the Submediterranean region [15].

In a preliminary attempt to assess the taxonomic status of $P$. nigra subsp. caudina ten trees from each of seven populations were studied for nuclear and chloroplast markers that have shown differences between species, subspecies, and single clones in Populus [15, 35-37]. One of the populations was a pure hairy type, three were hybrids and the others were typical spp. nigra. The results show no indication that the hairy type is a separate taxonomic unit because all the polymorphisms are the same as the ones of the European black poplars from Bosnia and Herzegovina, whether they are hairy or not. These results do not support the hypothesis of a possible tertiary relict [6] but rather they support the classification of the hairy type as a xeromorphic ecotype of the European black poplar. For the characterised strong trichome development on petiols of $P$. nigra subsp. caudina, candidate genes were analysed in order to understand the basis of its distinctness as well as the genetic variation $[38,39]$.

There are significant differences between the typical and hairy types of European black poplar in the studied morphological traits and these differences are in accordance with the climate differences in respective habitats of continental riparian forests and Submediterranean type of climate. 


\section{REFERENCES}

1. VANDEN BROECK A 2003 EUFORGEN Technical Guidelines for genetic conservation and use of European black poplar (Populus nigra). IPGRI, Rome, Italy, 6 p. URL: http://www.euforgen. org/fileadmin/bioversity/publications/pdfs/ EUFORGEN/927 Technical guidelines for genetic conservation and use for black poplar Populus nigra .pdf (2 December 2014)

2. KAJBA D, VRATARIĆ P 2000 Conservation of European black poplar (Populus nigra L.) genetic resources in Croatia. In: Isebrands JG, Richardson $J$ (eds) 21st Session of the IPC-2000: poplar and willow culture: meeting the needs of society and the environment, Vancouver, Canada, 24-28 September 2000. US Department of Agriculture, Forest Service, North Central Research Station, Gen Tech Rep NC-215, St Paul MN, USA, pp 87. URL: http://www.nrs.fs.fed.us/pubs/gtr/gtr nc215. pdf (2 December 2014)

3. BALLIAN D 2004 The status of black and white poplars (Populus nigra L., P. alba L.) in Bosnia and Herzegovina. In: Koskela J, de Vries SMG, Kajba D, von Wühlisch $G$ (eds) Populus nigra Network, Report of the seventh (25-27 October 2001, Osijek, Croatia) and eight (22-24 May 2003 Treppeln, Germany) meetings. IPGRI, Rome, Italy, pp 17-20

4. JANJIĆ N 1984 Prilog poznavanju svojti crne topole (P. nigra L.) u Bosni i Hercegovini. Glasnik Zemaljskog muzeja BiH u Sarajevu 23: 255-278

5. DZEKOV S 1960 Domašnata crna topola ( $P$. nigra) vo NR Makedonija. Godišen Zbornik na Zemjodelsko-šumarskiot fakultet, $44 \mathrm{p}$

6. PAPAIOANNOU J 1963 The Geographical Distribution of $P$. nigra var. pubescens Parl. and $P$. thevestina Dode and Their Hybrids. Food and Agriculture Organization of the United Nations, Rome, Italy, pp 1-15

7. BUGALA W 1967 Systematyka euroazjatyckich topoli z grupy $P$. nigra L. Rocznik Arboretum Kornickie 12: 47-220

8. PETERS RL 1990 Effects of global warming on forests. For Ecol Manag 35 (1-2): 13-33. DOI: http://dx.doi.org/10.1016/0378-1127(90)90229-5

9. ERWIN TL 1991 An evolutionary basis for conservation strategies. Science 253 (5021): 750-752. DOI: http://dx.doi.org/10.1126/ science. 253.5021 .750
10. ERIKSSON G, NAMKOONG G, ROBERDS JH 1993 Dynamic gene conservation for uncertain futures. For Ecol Manag 62 (1-4): 15-37. DOI: http://dx.doi. org/10.1016/0378-1127(93)90039-p

11. AITKEN SN, YEAMAN S, HOLLIDAY JA, WANG T, CURTIS-MCLANE S 2008 Adaptation, migration or extirpation: climate change outcomes for tree populations. Evol Appl 1: 95-111. DOI: http:// dx.doi.org/10.1111/j.1752-4571.2007.00013.x

12. CAGELLI L, LEFÉVRE $F 1995$ The conservation of Populus nigra and gene flow with cultivated poplars in Europe. Forest Genetics 2: 135-144

13. LEFÈVRE F, KAJBA D, HEINZE B, ROTACH P, DE VRIES SMG, TUROK J 2001 Black poplar: a model for gene resource conservation in forest ecosystems. Forest Chron 77 (2): 239-244. DOI: http://dx.doi. org/10.5558/tfc77239-2

14. LEFÈVRE $F$, BARSOUM N, HEINZE $B$, KAJBA D, ROTACH P, DE VRIES SMG, TUROK J 2001 EUFORGEN Technical Bulletin: In situ Conservation of Populus nigra. IPGRI, Rome, Italy, $58 \mathrm{p}$

15. KAJBA D, BALLIAN D, IDŽOJTIĆ M, BOGDAN S, 2004 The differences among hairy and typical European black poplars and the possible role of the hairy type in relation to climatic changes. For Ecol Manag 197 (1-3): 279-284. DOI: http://dx.doi. org/10.1016/j.foreco.2004.05.024

16. BISSOFFI S, CAGELLI L 1992 Leaf shape as a tool for the discrimination among poplar clones. 19th Session FAO/IPC, Zaragoza, Spain, FO:CIP:NR 92/2

17. ZSUFFA L 1974 The genetics of Populus nigra L. Annales Forestales 6 (2): 29-53

18. ECKENWALDER JE 1996 Systematics and evolution of Populus. In: Stettler RF, Bradshaw Jr HD, Heilman PE, Hinckley TM (eds) Biology of Populus and its Implications for Management and Conservation. National Research Council of Canada, NCR Research Press, Ottawa, Canada, pp 7-32

19. KRSTINIĆ A, TRINAJSTIĆ I, KAJBA D, SAMARDŽIĆ J 1997 Morphological variability of the leaves of black poplar (Populus nigra L.) in natural stands along the Sava river (Croatia). In: Turok J, Lèfevre F, de Vries S, Alba N, Heinze B, van Slycken J (eds) Populus nigra Network, Report of the fourth meeting, Geraardsbergen, Belgium, 3-5 October 1997. IPGRI, Rome, Italy, pp 71-77 
20. KAJBAD, IDŽOJTIĆM, BOGDANS 1999 Discriminant analysis of leaf morphological characters of the European Black Poplar (Populus nigra L.) in natural population in Croatia. In: Turok J, Lefévre $F$, de Vries S, Alba N, Heinze B, Voloyanchuk R, Lipman E (eds) Populus nigra Network, Report of the fifth meeting, Kyiv, Ukraine, 5-9 May 1999. IPGRI, Rome, Italy, pp 73-76

21. MAKSIMOVIĆ Z, ŠIJAČIĆ-NIKOLIĆ M 2013 Morphometric characteristics of black poplar (Populus nigra L.) leaves in the area of Great War Island. Bulletin of the Faculty of Forestry 108: 93108. DOI: http://dx.doi.org/10.2298/gsf1308093m

22. SOKAL RR, ROHLF FJ 1989 Biometry. Freeman and Co., San Francisco, CA, USA, 859 p

23. MCGARIGAL $K$, CUSHMAN S, STAFFORD S 2000 Multivariate statistics for wildlife and ecology research. Springer-Verlag, New York, NY, USA, 283 p. DOI: http://dx.doi.org/10.1007/978-1-46121288-1

24. KAISER HF 1960 The application of electronic computers to factor analysis. Educ Psychol Meast 20: 141-151. DOI: http://dx.doi. org/10.1177/001316446002000116

25. STATSOFT INC, 2001 STATISTICA (data analysis software system), version 8.0. URL: http://www. statsoft.com (4 December 2014)

26. KAJBA D, ROMANIĆ B 2002 Morphological leaf variability of the European black poplar (Populus nigra L.) in natural populations in the Drava River Basin in Croatia. In: van Damm B, Bordács S (eds) Genetic diversity in river populations of European Black Poplar - implications for riparian eco-system management, Szeksárd, Hungary, 16-20 May 2001. Csiszár Nyomda, Budapest, Hungary, pp 221-227

27. ŠILER B, SKORIĆ M, MIŠIĆ D, KOVAČEVIĆ B, JELIĆ M, PATENKOVIĆ A, KURBALIJA NOVIČIĆ Z 2014 Variability of European Black Poplar (Populus nigra L.) in the Danube Basin. Vojvodinašume, Novi Sad, $128 \mathrm{p}$.

28. RAJORA OP, ZSUFFA L, DANCIK BP 1991 Allozyme and Leaf Morphological Variation of Eastern Cottonwood at the Northern Limits of Its Range in Ontario. Forest Sci 37 (2): 688-702
29. BOŽIĆ G, HEINZE B，KAJBA D, KRYSTUFEK V, VANDEN BROECK A 2010 Genetic diversity in Populus nigra L. populations along rivers in Eastern Austria, Slovenia and Croatia as revealed by microsatellite markers. In: Spano $\mathrm{P}_{\text {, Cherubini }}$ L (eds) Fifth International Poplar Symposium, Poplars and Willows: from research models to multipurpose trees for a bio-based society, Orvieto, Italy, 20-25 September 2010, pp 22

30. POSPIŠKOVÁ M, ŠÁLKOVÁ I 2006 Population structure and parentage analysis of black poplar along the Morava River. Can J Forest Res 36 (5): 1067-1076. DOI: http://dx.doi.org/10.1139/x06$\underline{003}$

31. SMULDERS MJM, COTTRELL JE, LEFEVRE F, VAN DER SCHOOT J, ARENS P, VOSMAN B, TABBENER HE, GRASSI F, et al. 2008 Structure of the genetic diversity in black poplar (Populus nigra L.) populations across European river systems: Consequences for conservation and restoration. For Ecol Manag 255 (5-6): 1388-1399. DOI: http:// dx.doi.org/10.1016/j.foreco.2007.10.063

32. RATHMACHER G, NIGGEMANN M, KÖHNEN $M$, ZIEGENHAGEN B, BIALOZYT R 2010 Short-distance gene flow in Populus nigra L. accounts for smallscale spatial genetic structures: implications for in situ conservation measures. Conserv Genet 11 (4): 1327-1338. DOI: http://dx.doi.org/10.1007/ s10592-009-9961-6

33. BRUS R, GALIEN U, BOŽIČ G, JARNI K 2010 Morphological study of the leaves of two European black poplar (Populus nigra L.) populations in Slovenia. Period Biol 112 (3): 317-325

34. VANDEN BROECK A, COX K, VAN SLYCKEN J, HALFMAERTEN D 2000 Genetic pollution and mating systems in an artificial stand of black poplar (Populus nigra L.). In: Isebrands JG, Richardson J (eds) 21st Session of the IPC-2000: poplar and willow culture: meeting the needs of society and the environment, Vancouver, Canada, 24-28 September 2000. US Department of Agriculture, Forest Service, North Central Research Station, Gen Tech Rep NC-215, St Paul, MN, USA, pp 186

35. HEINZE B 1998 PCR-based chloroplast DNA assays for the identification of native Populus nigra and introduced poplar hybrids in Europe. Forest Genetics 5 (1): 31-38 
36. LEXER C, FAY MF, JOSEPH JA, NICA MS, HEINZE B 2005 Barrier to gene flow between two ecologically divergent Populus species, $P$. alba (white poplar) and $P$. tremula (European aspen): the role of ecology and life history in gene introgression. Mol Ecol 14 (4): 1045-1057. DOI: http://dx.doi. org/10.1111/j.1365-294x.2005.02469.x

37. KAJBA D, BALLIAN D, HEINZE B, IDŽOJTIĆ $M$, BOGDAN S 2004 Populus nigra ssp. caudina and ist importance for forest tree improvement and conservation of poplar genetic resources. In: ElLakany $\mathrm{MH}(\mathrm{ed}) 22^{\text {nd }}$ Session of the International Poplar Commission, The contribution of Poplars and Willows to Suistanable Forestry and Rural Development, Santiago, Chile, 29 November-2 December 2004. FAO, Rome, Italy, pp 29
38. KAJBA D, BALLIAN D, HEINZE B, IDŽOJTIĆ $M$, BOGDAN S, KATIČIĆ-TRUPČEVIĆ I 2005 Importance of Conservation of the Hairy Type of Populus nigra in the Changing Climatic and Environmental Conditions. In: Colić Franekić J, Ugarković $\square$ (eds) Second Congress of Croatian Geneticists, Supetar, Croatia, 24-27 September 2005. Croatian Genetic Society, Zagreb, Croatia, pp 90

39. HASE I, HEINZE B, ARTHOFER W, KAJBA D, BALLIAN D 2007 Candidate genes for hairness in poplar. Plant and Animal Genomes XV Conference, San Diego, USA, 13-17 January 2007

(C) 2015 by the Croatian Forest Research Institute. This is an Open Access paper distributed under the terms of the Creative Commons Attribution License (http://creativecommons.org/licenses/by/4.0). 